\title{
Neonatal screening for sickle cell diseases in Camberwell: results and recommendations of a two year pilot study
}

\author{
MARY E C HORN, MOIRA C DICK, BEVERLY FROST, L R DAVIS, A J BELLINGHAM, \\ C ERIC STROUD, J W STUDD
}

\begin{abstract}
The sickle cell diseases are a major health problem for Afro-Caribbean peoples. Neonatal detection and prophylactic management can reduce mortality and morbidity in childhood. $\mathbf{A}$ study was therefore conducted analysing the results of the first two years of cord blood screening in the Camberwell health area.

Thirteen cases of sickle cell disease and two of haemoglobin $(\mathrm{Hb}) \mathrm{C}$ disease were identified among 2202 non-white infants screened. The carrier state, sickle cell trait (HbAS), was present in $11.9 \%$ and $\mathrm{HbC}$ trait (HbAC) in $4.1 \%$ of Afro-Caribbean infants. The incidence of disease and of carrier states was much higher in West Africans than in Caribbeans. The wider implications of screening and the need for a comprehensive plan of care are emphasised.
\end{abstract}

\section{Introduction}

Many deaths from sickle cell diseases occur in childhood. In some parts of Central and West Africa survival to adulthood is unusual;

\footnotetext{
King's College Hospital, London SE5 8RX

MARY E C HORN, MB, DCH, research fellow, departments of haematology and child health

BEVERLY FROST, FIMLS, chief medical laboratory scientific officer, department of haematology

L R DAVIS, MD, FRCPATH, consultant haematologist

A J BELLINGHAM, MB, FRCP, professor of haematology

C ERIC STROUD, MB, FRCP, professor of child health

J W STUDD, MD, MRCOG, consultant obstetrician

Department of Haematology, Hammersmith Hospital, London W12 0HS MOIRA C DICK, MB, MRCP, Children Nationwide research registrar

Correspondence to: Dr Horn.
}

life expectancy is directly related to the availability of simple medical and social care. ${ }^{1}$ A prospective study in Jamaica showed that of 176 children diagnosed as having sickle cell disease at birth, $13 \%$ of those with haemoglobin $(\mathrm{Hb}) \mathrm{SS}$ and $6 \%$ with $\mathrm{HbSC}$ disease died within the first two years of life. ${ }^{2}$ In Los Angeles 422 patients of all ages with various forms of sickle cell disease were followed up prospectively for 10 years; of 49 who died, 15 (31\%) were less than 3 years old. ${ }^{3}$ In a survey of the disease in England and Wales 13 out of 37 of the reported deaths occurred in children aged 5 years or less, five of these being under 2 years old. ${ }^{+}$

Well documented hazards in the young child include overwhelming infection due to the early development of functional asplenia, ${ }^{56}$ liability to acute splenic sequestration, ${ }^{7}$ cerebrovascular accidents, ${ }^{8}$ and aplastic crises related to human parvovirus infection. ${ }^{9}$ The early introduction of prophylactic measures can reduce childhood mortality and morbidity. ${ }^{10-12}$

Cord blood diagnosis done when mother and infant are in close contact with the health services gives the best opportunity for identification, enrolment, and follow up in the sickle cell clinic, where parents may be counselled and educated about the disease and prophylaxis against pneumococcal infection can be introduced. Awareness by parents of the need for prompt medical attention in the event of illness improves the chance of successful management of infections and crises with antibiotics or blood transfusions, which may be life saving. The services for sickle cell disease in Camberwell were expanded in 1982 to include a programme of routine cord blood screening. We analyse the results of the first two years of this programme and examine its implications.

\section{Population and methods}

Camberwell covers the East Lambeth and South Southwark districts of south east London and has a population of 215000 . Obstetric services are provided by King's College and Dulwich hospitals. Some 3300 infants are delivered at the two hospitals each year. 
The term "white" was used to denote subjects of northern European origin only. All those of other ethnic groups were classified as non-white for screening purposes.

The ethnic origin of mothers attending the antenatal clinics was recorded at booking and non-white mothers screened for haemoglobinopathies. Cord blood samples were collected at delivery from the infants of these non-white mothers.

TABLE I-Ethnic origins of Camberwell mothers compared with inner London statistics for 1981

\begin{tabular}{|c|c|c|c|c|}
\hline \multirow[b]{2}{*}{ Ethnic origin } & \multicolumn{3}{|c|}{$\begin{array}{l}\text { Camberwell mothers } \\
\qquad(n=6540)\end{array}$} & \multirow{2}{*}{$\begin{array}{c}\text { Population of } \\
\text { inner London } \\
(\mathrm{n}=2348000) \\
(\%)\end{array}$} \\
\hline & & No & $\%$ & \\
\hline Non-white & & 2555 & $39 \cdot 1$ & $18 \cdot 4$ \\
\hline Caribbean & 1004 & 1401 & $15 \cdot 3\} 21 \cdot 4$ & $8 \cdot 4$ \\
\hline African & $397\}$ & 1401 & $6 \cdot 1\}^{21 \cdot 4}$ & $1 \cdot 4$ \\
\hline Asian & 364 & & $5 \cdot 6$ & $4 \cdot 6$ \\
\hline Mediterranean/ & & & & \\
\hline mixed/other & 385 & & $5 \cdot 9$ & $4 \cdot 0$ \\
\hline Unspecified & 405 & & $6 \cdot 2$ & \\
\hline White & & 3985 & $60 \cdot 9$ & $76 \cdot 4$ \\
\hline Unknown & & & & $5 \cdot 2$ \\
\hline Total & & 6540 & $100 \cdot 0$ & $100 \cdot 0$ \\
\hline
\end{tabular}

London $^{15}$ (table I). Among the total population of mothers $21.4 \%$ were known to be in the high risk Afro-Caribbean group: the ratio of Caribbeans to Africans was 2:5:1. Most of the Caribbeans came from the West Indies and most of the Africans from Nigeria or Ghana.

Screening was carried out in 2202 of the 2569 infants (including 14 twins) of non-white mothers, 2114 by cord blood sampling and 88 by capillary samples taken during the first week of life. Screening was "missed" in the remaining 367 infants, 118 of whom were Caribbean and 40 African. Table II shows the numbers of infants screened in each ethnic group and the abnormalities detected. The results in 406 non-white infants whose mothers' exact ethnic origin was unspecified are listed separately.

One or more abnormalities were detected in 525 samples $(23.8 \%)$ including 318 containing $\mathrm{Hb}$ Barts alone or in combination with other defects. Thirteen cases of sickle haemoglobinopathy and two of $\mathrm{HbC}$ disease were diagnosed from cord blood samples. One late diagnosis of the rare SD disease in an infant who had not been screened at birth is included in the incidence.

The overall incidence of sickle cell disease was $0.6 \%$ and of $\mathrm{HbC}$ disease $0 \cdot 1 \%$. All cases occurred in Afro-Caribbeans, with the exception of the child with $\mathrm{HbSD}$ disease, whose mother was white-Caribbean and father white. The incidence of sickle cell disease, heterozygous states, and $\alpha_{2}$ thalassaemia was substantially higher in Africans than in Caribbeans (table III). Gene frequencies of abnormal haemoglobins and the expected relative frequency of $\mathrm{Hb}$ phenotypes were calculated according to the Hardy-Weinberg law (tables IV, V). The distribution of phenotypes observed was similar to that predicted except in the case of HbSC disease, which was more frequent than expected.

TABLE II-Distribution of haemoglobin phenotypes in newborn infants of mothers of the various ethnic origins

\begin{tabular}{|c|c|c|c|c|c|c|c|c|c|c|c|c|}
\hline \multirow[b]{2}{*}{ Infants' haemoglobin phenotype } & \multicolumn{2}{|c|}{ Caribbean } & \multicolumn{2}{|c|}{ African } & \multicolumn{2}{|c|}{ Asian } & \multicolumn{2}{|c|}{$\begin{array}{l}\text { Mediterranean } \\
\text { mixed/other }\end{array}$} & \multicolumn{2}{|c|}{$\begin{array}{l}\text { Non-white, } \\
\text { unspecified }\end{array}$} & \multicolumn{2}{|c|}{ Total } \\
\hline & No & $\%$ & No & $\%$ & No & $\%$ & No & $\%$ & No & $\%$ & No & $\%$ \\
\hline $\mathrm{AA}(\mathrm{AF})$ & 656 & $73 \cdot 5$ & 194 & $53 \cdot 7$ & 249 & $94 \cdot 3$ & 242 & $86 \cdot 7$ & 336 & $82 \cdot 8$ & 1677 & $76 \cdot 1$ \\
\hline $\begin{array}{l}\text { AS } \\
\text { AC } \\
\text { AD } \\
\text { AE }\end{array}$ & $\begin{array}{l}77 \\
33 \\
- \\
-\end{array}$ & $\begin{array}{l}8 \cdot 6 \\
3 \cdot 7 \\
- \\
-\end{array}$ & $\begin{array}{r}72 \\
19 \\
1 \\
-\end{array}$ & $\begin{array}{r}19 \cdot 9 \\
5 \cdot 3 \\
0 \cdot 3 \\
-\end{array}$ & $\frac{-}{1}$ & $\begin{array}{l}\overline{-} \\
0 \cdot 4 \\
1 \cdot 1\end{array}$ & $\begin{array}{r}5 \\
1 \\
2 \\
-\end{array}$ & $\begin{array}{l}1 \cdot 8 \\
0 \cdot 4 \\
0 \cdot 7 \\
-\end{array}$ & $\begin{array}{r}26 \\
6 \\
- \\
-\end{array}$ & $\begin{array}{l}6 \cdot 4 \\
1 \cdot 5 \\
- \\
-\end{array}$ & $\begin{array}{r}180 \\
59 \\
4 \\
3\end{array}$ & $\begin{array}{l}8 \cdot 2 \\
2 \cdot 7 \\
0 \cdot 2 \\
0 \cdot 1\end{array}$ \\
\hline $\begin{array}{l}\text { SS } \\
\text { SC } \\
\text { SD } \\
\text { S } \beta^{+} \text {Thalassaemia }\end{array}$ & $\begin{array}{r}1 \\
\frac{3}{2}\end{array}$ & $\begin{array}{l}0 \cdot 1 \\
0 \cdot 3 \\
\frac{0 \cdot 2}{0 \cdot 2}\end{array}$ & $\begin{array}{l}4 \\
3 \\
- \\
-\end{array}$ & $\begin{array}{l}1 \cdot 1 \\
0 \cdot 8 \\
- \\
-\end{array}$ & $\begin{array}{l}- \\
z \\
z\end{array}$ & $\begin{array}{l}- \\
- \\
-\end{array}$ & $\overline{1}$ & $\frac{-}{0 \cdot 4}$ & $\begin{array}{l}- \\
\overline{-} \\
-\end{array}$ & $\begin{array}{l}- \\
z \\
-\end{array}$ & $\begin{array}{l}5 \\
6 \\
1 \\
2\end{array}$ & $\begin{array}{l}0 \cdot 3 \\
0 \cdot 3 \\
0 \cdot 05 \\
0 \cdot 1\end{array}$ \\
\hline $\begin{array}{l}\mathrm{CC} \\
\mathrm{AF} \text { Barts }\end{array}$ & $\begin{array}{r}2 \\
118\end{array}$ & $\begin{array}{r}0 \cdot 2 \\
13 \cdot 2\end{array}$ & $\overline{68}$ & $\overline{18 \cdot 8}$ & $\overline{11}$ & $\overline{4 \cdot 2}$ & $\overline{28}$ & $\overline{10 \cdot 0}$ & $\overline{38}$ & $\overline{9 \cdot 4}$ & $\begin{array}{r}2 \\
263\end{array}$ & $\begin{array}{r}0 \cdot 1 \\
11 \cdot 9\end{array}$ \\
\hline Total & 892 & $100 \cdot 0$ & 361 & $100 \cdot 0$ & 264 & $100 \cdot 0$ & 279 & $100 \cdot 0$ & 406 & $100 \cdot 0$ & 2202 & $100 \cdot 0$ \\
\hline $\begin{array}{l}\text { ASHPFH }{ }^{\star} \dagger \\
\text { AFS Barts } \\
\text { AFC Barts` }\end{array}$ & $\begin{array}{r}1 \\
14 \\
6\end{array}$ & $\begin{array}{l}0.1 \\
1.6 \\
0.7\end{array}$ & $\begin{array}{r}-79 \\
7\end{array}$ & $\begin{array}{l}\overline{5 \cdot 3} \\
1 \cdot 9\end{array}$ & - & E & $\overline{2}$ & $\begin{array}{l}\overline{0 \cdot 7} \\
-\end{array}$ & $\frac{\overline{7}}{-}$ & $\begin{array}{l}\overline{1 \cdot 7} \\
-\end{array}$ & $\begin{array}{r}1 \\
42 \\
13\end{array}$ & $\begin{array}{l}0.05 \\
1.9 \\
0.6\end{array}$ \\
\hline Total samples with Hb Barts & 138 & $15 \cdot 5$ & 94 & $26 \cdot 0$ & 11 & $4 \cdot 2$ & 30 & $10 \cdot 8$ & 45 & $11 \cdot 1$ & 318 & $14 \cdot 4$ \\
\hline
\end{tabular}

* Included in AS or AC above.

t ASHPFH $=$ HbAS in combination with hereditary persistence of fetal haemoglobin

Samples were placed in edetic acid containers and stored at $4^{\circ} \mathrm{C}$ until tested. Haemolysates were prepared by adding a saponin-cyanide mixture to once washed packed red cells followed by vortex mixing. Alkaline zone electrophoresis was carried out on cellulose acetate membrane in Shandon apparatus, using a discontinuous buffer system with trometamol (TRIS)edetic acid-borate buffer $\mathrm{pH} 9 \cdot 1$ at the anode and barbitone buffer $\mathrm{pH} 8.6$ at the cathode. ${ }^{13}$ The cellulose acetate membrane strips were examined by transillumination for $\mathrm{HbA}$ and $\mathrm{Hb}$ Barts. All samples with a variant haemoglobin or where the presence of $\mathrm{HbS}$ was doubtful were then run on citrate agar gel electrophoresis at $\mathrm{pH} 6 \cdot 0^{14}$ using Gelbond as the support medium. Samples containing $\mathrm{Hb}$ Barts were diagnosed as $\alpha_{2}$ thalassaemia; quantitative measurements to determine the incidence of homozygous compared with heterozygous states were not undertaken because of the time consuming nature of the investigation.

\section{Results}

During the two years of the study (25 May 1982 to 24 May 1984) 6540 mothers were delivered of 6615 infants at King's College and Dulwich hospitals. The ethnic origins of the mothers were derived from the birth registers and compared with the 1981 population statistics for inner
Haemoglobin electrophoresis results were seldom available before the discharge of mother and infant from hospital. The health visitor was informed of any cases of sickle cell disease diagnosed and a letter sent to the mother giving an appointment for the children's sickle cell clinic. Satisfactory follow up was attained in 14 out of 15 cases. The remaining child could not be traced and was thought to have left Britain.

TABLE III-Percentage incidences of haemoglobinopathies and heterozygous states in Caribbeans and Africans

\begin{tabular}{lccc}
\hline Haemoglobin phenotype & $\begin{array}{c}\text { Caribbeans } \\
(\mathrm{n}=892)\end{array}$ & $\begin{array}{c}\text { Africans } \\
(\mathrm{n}=361)\end{array}$ & $\begin{array}{c}\text { All } \\
\text { Afro-Caribbeans } \\
(\mathrm{n}=1253)\end{array}$ \\
\hline SS & $0 \cdot 1$ & $1 \cdot 1$ & $0 \cdot 4$ \\
SC & $0 \cdot 3$ & $0 \cdot 8$ & $0 \cdot 5$ \\
S ${ }^{+}$Thalassaemia & $0 \cdot 2$ & - & $0 \cdot 2$ \\
All sickle cell disease & $0 \cdot 7$ & $1 \cdot 9$ & $1 \cdot 1$ \\
CC & $0 \cdot 2$ & - & $0 \cdot 2$ \\
AS & $8 \cdot 6$ & $19 \cdot 9$ & $11 \cdot 9$ \\
AC & $3 \cdot 7$ & $5 \cdot 3$ & $4 \cdot 1$ \\
AD & - & $0 \cdot 3$ & $0 \cdot 2$ \\
$\alpha_{2}$ Thalassaemia (Hb Barts) & $15 \cdot 5$ & $26 \cdot 0$ & $18 \cdot 5$ \\
\hline
\end{tabular}


On first attendance at the clinic haemoglobin electrophoresis was repeated to confirm the diagnosis. A revised diagnosis of $\mathrm{HbC}$ trait was made in one case originally thought to be $\mathrm{HbC}$ disease. Both patients with $\mathrm{HbS} \beta$ thalassaemia had developed detectable amounts of $\mathrm{HbA}$ and were confirmed as $\mathrm{HbS} \beta^{+}$thalassaemia.

Heterozygote results were not communicated to parents unless requested.

Cost of screening-The overall cost of screening including labour and materials was estimated as $£ 1 \cdot 70$ per sample. All samples in which an abnormality was detected were re-examined by agar gel electrophoresis at a further cost of $£ 1 \cdot 70$. During the two years of study the cost of screening will have sickle cell disease and many will not be identified at birth. Screening all infants at birth for haemoglobinopathies would not at present be cost effective, since the incidence of heterozygous states in white people is extremely low. Increasing intermarriage between ethnic groups will, however, eventually lead to wider distribution of heterozygous states, necessitating comprehensive screening. In future it is hoped that current work to improve the accuracy of the method of spot testing on filter paper will lead to its incorporation in the established neonatal screening programme for amino acid

TABLE IV-Relative gene frequencies of haemoglobins ${ }^{\star}$

\begin{tabular}{lcccccc}
\hline & \multicolumn{5}{c}{ Haemoglobin } & \\
\cline { 2 - 5 } & $\mathrm{A}$ & $\mathrm{S}$ & $\mathrm{C}$ & $\mathrm{D}$ & $\mathrm{E}$ & Total \\
\hline $\begin{array}{l}\text { No } \\
\text { Relative frequency }\end{array}$ & 0.9373297 & 0.0451861 & 0.0156675 & 0.0011353 & 0.0006811 & 0.9999997
\end{tabular}

* $\beta$ Thalassaemia genes excluded since true incidence cannot be determined by haemoglobin electrophoresis at birth

TABLE V-Haemoglobin phenotypes predicted and observed

\begin{tabular}{lcrr}
\hline Phenotype & $\begin{array}{c}\text { Expected relative } \\
\text { frequency }\end{array}$ & No expected & No observed \\
\hline AA & 0.8785869 & 1934 & 1942 \\
AS & 0.0847084 & 186 & 180 \\
AC & 0.0293712 & 65 & 59 \\
AD & 0.0021282 & 5 & 4 \\
AE & 0.0012768 & 5 & 5 \\
SS & 0.0020417 & 3 & 6 \\
SC & 0.0014158 & $<1$ & 1 \\
SD & 0.0001024 & $<1$ & 2 \\
SE & 0.0000614 & $<1$ & 2202 \\
CC & 0.0002454 & 2202 & \\
\hline Total & 0.9999382 & & \\
\hline
\end{tabular}

2202 infants, of whom 580 were double checked, was $£ 4729 \cdot 40$; the cost of detecting each of the 16 infants with sickle cell or $\mathrm{HbC}$ disease was therefore $£ 295 \cdot 59$.

\section{Discussion}

The frequency of sickle cell disease in Afro-Caribbeans is higher than that of any other group of hereditary disorders for which neonatal screening is currently advocated. Screening is therefore fully justifiable, particularly as prophylactic measures lead to a reduction in early mortality and morbidity from the disease.

The number of major haemoglobinopathies identified in the two years of neonatal screening in Camberwell was much as predicted. The incidence of HbSS disease in Afro-Caribbeans was slightly lower than in Brent ${ }^{16}$ but findings were otherwise similar in the two districts, where the percentage and distribution of Africans $(28 \%)$ and Caribbeans $(72 \%)$ are identical. The results show only minor differences from those of studies in the United States ${ }^{1718}$ and from the large Jamaican survey of 70000 newborn infants. ${ }^{19}$ In Camberwell sickle cell trait was found in $8.6 \%$ and $\mathrm{HbC}$ trait in $3.7 \%$ of Caribbean infants compared with $10.0 \%$ and $3.6 \%$ respectively in the Jamaican series. The incidence of sickle cell trait derived from studies in Africans living in Ghana and Nigeria $(20 \cdot 7 \%)^{20}$ was almost the same as that in Africans in Camberwell (19.9\%), emphasising the exceptionally high risk of sickle cell disease in these families. Gene frequencies in Afro-Caribbean infants in this study were comparable to those found in Jamaica.

The exact number of births to black mothers born in Africa and the Caribbean and living in London is not available, since Caribbeans were underestimated in the last census (Office of Population Censuses and Surveys, personal communication, 1985). Nevertheless, probably between 4500 and 5000 infants at risk are delivered each year in inner London alone: assuming an overall incidence of at least $1 \cdot 1 \%$, as in Camberwell, $50-55$ of these infants disorders and hypothyroidism. In the mean time, if screening is to be confined to the infants of non-white mothers accurate recording of ethnic origin and methods of double checking are essential. Theoretically only the infants of mothers with abnormal haemoglobin electrophoresis need be tested, but in practice screening all infants is expedient to avoid the error of "missing" infants at risk, as occurred in this study.

Two reasons for omitting cord blood screening were identifiedfirstly, preoccupation with obstetric problems and resuscitation (as occurred in the infant with $\mathrm{HbSD}$ disease) and, secondly, failure of briefing related to frequent staff rotation.

$\alpha_{2}$ Thalassaemia, like hereditary persistence of fetal haemoglobin, modifies the severity of sickle cell disease. ${ }^{2122}$ It may be diagnosed by finding $\mathrm{Hb}$ Barts on haemoglobin electrophoresis in the first weeks of life. In this study $\mathrm{Hb}$ Barts was present in $18.5 \%$ of Afro-Caribbeans compared with 30\% found in the black American population. ${ }^{23}$ The difference may be explained by the fact that in homozygous $\alpha_{2}$ thalassaemia $\mathrm{Hb}$ Barts is readily identifiable but in the heterozygous state minute amounts may be detected only by quantitative measurements or gene mapping. In future quantitative measurements of $\mathrm{Hb}$ Barts would be of prognostic value in infants diagnosed as having sickle cell disease. Serjeant recommends the accurate identification of $\alpha_{2}$ thalassaemia and hereditary persistence of fetal haemoglobin, which, together with socioeconomic deprivation, are some of the factors accounting for the wide range of severity in sickle cell disease. ${ }^{19}$

Maternal and neonatal screening must be backed by an adequate counselling service. It is strongly recommended that at least one specially trained health worker should be employed in the antenatal clinic to educate mothers about the disease and gain their confidence in the screening programme. Contact with heterozygous mothers in the antenatal period gives an opportunity to screen fathers and other members of the family and to give genetic advice. Distress and disbelief have been encountered in some mothers of affected infants who have not been told beforehand about the possibility of sickle cell disease. This can be avoided by contact with the health visitor in the antenatal period. Early communication of the results and transfer to a paediatric haematology or sickle cell clinic should ensure continuity of support. In the absence of expert counselling routine notification of parents whose infants are heterozygous is of no immediate value and may cause unnecessary anxiety.

Although the primary object of screening in the neonatal period is to reduce childhood morbidity and mortality, wide social issues are implicated. A major programme of education and screening is needed for the two thirds of a million black people living in Great Britain. More emphasis must be placed on sickle cell disease in the education of doctors and nurses and short specialised courses are needed for health visitors undertaking counselling in family planning and antenatal clinics. A recent survey of screening and counselling in England has been valuable in drawing attention to the need for easily accessible, competently staffed sickle cell centres 
where black people can obtain information and arrange for screening. ${ }^{24}$ Those who are heterozygous for abnormal haemoglobins or $\beta$ thalassaemia can then receive genetic counselling and learn about recent developments such as prenatal diagnosis.

The educational and screening programme for $\beta$ thalassaemia major among eastern Mediterranean peoples has led to a dramatic fall in the incidence of that disease and provides hope that a similar approach might also, in time, reduce the tragically high incidence of sickle cell disease.

\section{References}

1 Konotey-Ahulu FID. The sickle cell diseases. Arch Intern Med 1974;133:611-9.

2 Rogers DW, Clarke JM, Cupidore L, Ramlal AM, Sparke BR, Serieant GR. Early deaths in Jamaican children with sickle cell disease. $B r$ Med $\mathcal{F}$ 1978;i:1515-6.

3 Powars DR. Natural history of sickle cell disease-the first ten years. Semin Hematol 1975;12: 267-85.

4 Davis LR, Huehns ER, White JM. Survey of sickle cell disease in England and Wales. Br Med $\mathcal{J}$ $1981 ; 283: 1519-21$

5 Pearson HA, McIntosh S, Ritchey AK, Lobel JS, Rooks Y, Johnston D. Developmental aspects of splenic function in sickle cell diseases. Blood 1979;53:358-65.

6 Rogers DW, Serjeant BE, Serjeant GR. Early rise in 'pitted' red cell count as a guide to susceptibility to infection in childhood sickle cell anaemia. Arch Dis Child 1982;57:338-42.

7 Topley JM, Rogers DW, Stevens MCG, Sergeant GR. Acute splenic sequestration and hypersplenism in the first five years in childhood sickle cell anaemia. Arch Dis Child 1981;56:765-9

8 Sarnaik SA, Lusher JM. Neurological complications of sickle cell anemia. Am $\mathcal{f}$ Pediatr Hematol Oncol 1982;4:386-94.
9 Anderson MJ, Davis LR, Hodgson J, et al. Occurrence of infection with a parvo-virus-like agent in children with sickle cell anaemia during a two-year period. F Clin Pathol 1982;35:744-9.

10 Steinberg N, Warren MS, Carter TP, Humbert JR, Rowley PT. Newborn screening for hemoglobinopathies in New York state: experience of physicians and parents of affected children. F Pediatr 1982;100:373-7.

11 Murtaza LM, Stroud CE, Davis LR, Cooper DJ. Admissions to hospital of children with sickle cell anaemia: a study in south London. Br Med $\mathcal{F} 1981 ; 282: 1048-5$

12 Nussbaum RL, Powell C, Graham HL, Caskey CT, Fernback DJ. Newborn screening for sickling hemoglobinopathies. Houston 1976 to 1980 . Am $\mathcal{J}$ Dis Child 1984;138:44-8.

13 Graham JL, Grunbaum BW. A rapid method for micro-electrophoresis and quantitation of hemoglobins on cellulose acetate. Am $\mathcal{Y}$ Clin Pathol 1963;39:567-78.

14 Robinson AR, Robson M, Harrison AP, Zuelzer WW. A new technique for differentiation of hemoglobin. 7 Lab Clin Med 1957;50:745-52.

15 Office of Population Censuses and Surveys. Labour force survey 1981. Series LFS No 3 Country of birth, ethnic origin and nationality. Ch 5 . London: HMSO, 1982:32.

16 Henthorn J, Anionwu E, Brozovic M. Screening cord blood for sickle haemoglobinopathies in Brent. Br Med F 1984;289:479-80.

17 Pearson HA, O'Brien RT, McIntosh S, Aspnes GT, Yang M. Routine screening of umbilical cord Pearson HA, O'Brien RT, McIntosh S, Aspnes GT, Yan
blood for sickle cell diseases. JAMA 1974;227:420-1.

18 Grover R, Wethers D, Shahidi S, Grossi M, Goldberg D, Davidow B. Evaluation of the expanded newborn screening program in New York City. Pediatrics 1978;61:740-9.

19 Serjeant GR. Observations on the epidemiology of sickle cell disease. Trans R Soc Trop Med Hyg $1981 ; 75: 228-33$.

20 Serieant GR. Observations on the epidemiology of sickle cell disease. Vol 4. Amsterdam-Oxford: North Holland Publishing Company, 1974:38.

21 Embury SH, Dozy AM, Miller J, et al. Concurrent sickle cell anemia and $\alpha$-thalassemia. Effect on severity of anemia. N Engl f Med 1982;306:270-4.

22 Higgs DR, Aldridge BE, Lamb J, et al. The interaction of alpha-thalassenia and homozygous sickle-cell disease. $N$ Engl I Med 1982;306:1441-6.

23 Dozy $\mathrm{AM}, \mathrm{Kan} \mathrm{YW}$, Embury $\mathrm{SH}$, et al. $\alpha$-Globin gene organisation in blacks precludes the severe form of $\alpha$-thalassaemia. Nature 1979;280:605-7.

24 Prashar O, Anionwu E, Brozovie M. Sickle cell anaemia-Who cares? London: The Runnymede Trust, 1985 .

(Accepted 2 December 1985)

\section{WORDS}

MEDICAL AND LEGAL TERMINOLOGY - SOME DIFFERENCES. In their respective professional activities doctors and lawyers share a small patch of common ground. Misunderstandings between the professions, which may arise despite the best of intentions, are especially likely to occur when the relationship is adversarial. The reasons for this are partly semantic and partly cultural, by which I mean the result of differences in traditional patterns of thinking. The law is manmade; its definitions are precise, and when a definition appears to be unclear or ambiguous, often as the result of the wording of a statute, a judge of the court will establish an interpretation. By contrast, the science and art of medicine are based on disorders of bodily or mental function which are incompletely understood. When in doubt opinions regarding diagnosis or prognosis tend, therefore, to be based on probabilities, which in turn rest on evidence that is often incomplete. Let us see how this affects the choice of words used by these two professions. I shall take two extreme examples in order to contrast the difference.

When wishing to opine regarding the diagnosis, trend, or prognosis of a disorder, a doctor may be able to quote figures of probability based on similar cases, but in the mundane situations of clinical practice figures are not usually available. The doctor is then obliged to draw on experience, which may be described as cumulative memory, often fallible, which is then modified by personal bias. There is now available a range of terms from which to choose, as follows. It passes from "almost certainly," through "very probably" and "probably," to "commonly" and "not uncommonly" (very popular), "occasionally," "uncommonly," and "rarely," to "hardly ever," but carefully avoiding the pitfalls of "always" and "never."

Now lawyers are trained in the techniques of closing loopholes, leaving no stones unturned, and exploring every avenue. This is obviously of great importance when, for example, framing a criminal charge or drafting a contract. But sometimes this obsession for ultimate precision goes to their heads, and the example that follows is of a summons to attend an inquest which I received some years ago. The present day wording is less pernickety, but this does not invalidate my theme.

The County of London to wit

By Virtue of a Warrant under the Hand and Seal of $\mathrm{H}$ N Stafford, Esquire, one of His Majesty's Coroners for the County of London, You are hereby summoned to be and appear before him on Thursday, the 15th day of February at 950 am o'clock precisely in the forenoon at the Coroner's Court 77 Fulham Palace Road Hammersmith then and there to give evidence on His Majesty's behalf touching the death of S E Joyce Herein fail not at your peril.

Dated this 13th day Feb 1940

\section{Mitchley CONSTABLE}

We can ignore the superfluity of capitalised initials as a stylistic quirk.

"to wit." A redundant archaism that prompts the reply, "O Constable, let it be wist I wot well what thou wottest."

"Hand and Seal." The "hand" (signature) is that of D Mitchley, the coroner's officer. The seal was not applied to the document; perhaps the wax was "in short supply."

"to be and appear." Yes, both simultaneously. Without the combined act one might frustrate HM Coroner's summons by being without appearing. I could, for example, attend the court boxed into a packing case, with holes for ventilation and the audibility of my voice. The reverse is also possible; could appear without being before him by standing outside the courtroom window and giving evidence by hand signals. (I mean, you can't be too careful with these doctors.)

"then and there." Similarly, there must be a coincidence of time and place. Otherwise I might choose to give evidence then but not there-by telephone or closed circuit TV. After all, the great auction houses accept bids of many thousands of pounds on the strength of such mediate communication. The reverse, "there" but not "then," would tempt me perhaps to turn up when everyone else has gone to lunch, or at the right time on the wrong day.

"Herein fail not at your peril." This threat causes me much disquiet. What horrid fate awaits me if I attend not "precisely" but one minute early? "We have spare room in the mortuary, sir." "No, not that!" "All right, seven days in custody for contempt of court." "Thank you, that will be most acceptable after an 80 hour week on duty."

"to give evidence on His Majesty's behalf." What exactly are they driving at? Is the King to give evidence? Apparently not; I am to give it on his behalf. Or is the coroner under the delusion that he is the King? Help, Kafka, let me out!-B J FREEDMAN.

A patient with persistent abdominal pain for which no cause has been found has heard of a technique for pain relief using implanted electrodes. What is the technique and is it effective?

Electrodes are positioned over the dorsal column of the spinal cord. An external transmitter then activates a subcutaneous radiotelemetric receiver. This technique may help a few patients, usually those with deafferentation pain-for instance, postherpetic neuralgia. It would be unlikely to help pain of visceral origins. A positive response to transcutaneous nerve stimulation will help define further those patients who might benefit from implanted electrodes. Transcutaneous nerve stimulation is probably without hazard and should be tried before considering invasive techniques. It has a variable success rate between $20 \%$ and $70 \%$ but long term its success wanes considerably. Many patients can be helped by this simple technique but some are unable to tolerate the surface electrodes. This group could then be considered for implanted dorsal column stimulation.-C G CLOUGH, senior neurological registrar, Birmingham. 